\title{
Correction to: Institutions and corporate financial distress in Central and Eastern Europe
}

\author{
Nicolae Stef ${ }^{1}$ (1)
}

Accepted: 14 June 2021 / Published online: 19 June 2021

(c) Springer Science+Business Media, LLC, part of Springer Nature 2021

\section{Correction to: European Journal of Law and Economics https://doi.org/10.1007/s10657-021-09702-9}

The original version of this article unfortunately contained a typographical error in the abstract. The original article has been corrected.

The correct abstract is given below:

After a long period of economic and legal transition, new institutions emerged in Central and Eastern Europe (CEE). Firms facing financial difficulties must cope with the quality of those institutions. This study investigates the association between the institutional environment and a firm's recovery from financial distress. Our analysis relies on a sample of $823 \mathrm{CEE}$ listed firms subject to financial difficulties over the period from 2004 to 2017. After controlling for the endogeneity of institutional quality and financial features, dynamic panel estimates confirm that increased anticorruption efforts contributed to restoring the financial health of CEE firms. By reducing costs resulting from bribes and bureaucracy, efficient anticorruption mechanisms can facilitate firm efforts to overcome financial distress. In addition, several CEE countries created anticorruption agencies, mainly prior to the financial crisis or at the beginning of the postcrisis period. This may partially explain why anticorruption institutions were able to produce positive externalities. The development and independence of such agencies should be highly encouraged in CEE, as financially distressed firms may benefit from anticorruption policies.

The original article can be found online at https://doi.org/10.1007/s10657-021-09702-9.

Nicolae Stef

nicolae.stef@bsb-education.com

1 CEREN EA 7477, Department of Accounting, Finance \& Law, Burgundy School of Business, Université Bourgogne Franche-Comté, Dijon, France 
Publisher's Note Springer Nature remains neutral with regard to jurisdictional claims in published maps and institutional affiliations. 